Article

\title{
Improved Accumulation Capabilities of Phosphorus and Potassium in Green Manures and Its Relationship with Soil Properties and Enzymatic Activities
}

\author{
Farheen Solangi, Jinshun Bai, Songjuan Gao, Lu Yang, Guopeng Zhou and Weidong Cao * \\ Institute of Agricultural Resources and Regional Planning, Chinese Academy of Agricultural Sciences (CAAS), \\ No.12 Zhongguancun South Street, Haidian District, Beijing 100081, China; feryssolangi@yahoo.com (F.S.); \\ baijinshun@caas.cn (J.B.); gaosongjuan@caas.cn (S.G.); luckyyl_520@163.com (L.Y.); \\ zhouguopeng29@163.com (G.Z.) \\ * Correspondence: caoweidong@caas.cn; Tel.: +86-135-2181-7397
}

Received: 13 September 2019; Accepted: 28 October 2019; Published: 1 November 2019

\begin{abstract}
Cultivation of green manure crops is important strategy for improving soil fertility in South China. Therefore, it is important to obtain plant varieties that can better accumulate nutrients during the green manuring phase. The present study evaluated the phosphorus $(\mathrm{P})$ and potassium $(\mathrm{K})$ uptake efficiencies of various winter leguminous species at two different sites. Varieties tested included six Chinese milk vetch cultivars (i.e., Minzi No.6, Ningbodaqiao, Wanzi No.1, Xiangzi No.1, Yijiangzi, and Yujiangdaye), as well as hairy vetch and common vetch, while ryegrass was planted as a control. All leguminous species showed higher ability for $\mathrm{P}$ and $\mathrm{K}$ absorption in the two sites compared to the ryegrass. Hairy vetch and common vetch performed better than all six Chinese milk vetch cultivars, and the highest biomass and $\mathrm{P}$ and $\mathrm{K}$ uptake capacities were observed in hairy vetch. Green manuring had different effects on soil enzymes. Phosphatase (87.0\%) and leucine-aminopeptidase $(163.8 \%)$ were increased by hairy vetch. $\beta$-glucosidase $(143.4 \%)$ and $\mathrm{N}$-acetyl-glucosaminidase $(283.3 \%)$ were increased by Yijiangzi and Yujiangdaye, respectively, in Guangxi compared to the control. Xiangzi No.1 increased N-acetyl-glucosaminidase (352.6\%), leucine-aminopeptidase (477.5\%), phosphatase (591\%), and $\beta$-glucosidase (786.0\%) in Hunan compared to the ryegrass. Enzyme activities increased nutrient availability at both experimental sites. $\mathrm{P}$ and $\mathrm{K}$ uptake efficiencies significantly related with soil enzymes in Guangxi. It is suggested that hairy vetch has the largest capability for $\mathrm{P}$ and $\mathrm{K}$ uptake and might be a potential choice for improving $\mathrm{P}$ and $\mathrm{K}$ management in sustainable agriculture.
\end{abstract}

Keywords: leguminous species; soil enzymes; nutrient availability; P and K uptake

\section{Introduction}

Phosphorus $(\mathrm{P})$ and potassium $(\mathrm{K})$ are the most significant macronutrients in the soil ecosystem after nitrogen $(\mathrm{N})$ [1,2], which involves various processes, i.e., energy formation, nucleic acid synthesis, photosynthesis, glycolysis, respiration, enzymes activation and redox reactions $[3,4]$. Nutrient management is important for sustainable crop production. P- and K-efficient cultivars are important options in an agro-ecosystem [5]. Uptake efficiencies of nutrients such as $\mathrm{P}$ and $\mathrm{K}$ are related to the abilities of plants to produce high yields in low-nutrient conditions [6]. Deficiency in P is mainly attributed to its immobilization in soil [7]. Low K content is highly dependent on soil composition, especially on its fixation to clay particles, leading to deficiency in plant uptake [8]. Immobilized P can be re-mobilized, and non-exchangeable $\mathrm{K}$ can also become available in soil solution under biochemical processes [6]. However, they could be strongly dependent on soil chemistry [9] Exploitation of legumes is an essential approach for sustainable agriculture as it can increase nutrient cycling and promote 
soil fertility [10] This approach can also potentially improve P and K availability in the soil, which is beneficial for plant uptake and soil microorganisms [11,12]. Root growth and root morphological mechanisms of leguminous plants are the principal factors that usually require greater $\mathrm{P}$ and $\mathrm{K}$ levels in the soil, which is also related to plant $\mathrm{P}$ and $\mathrm{K}$ uptake $[13,14]$. Several green manure crops such as white lupin (Lupines albas L.), chickpea (Cicer arietinum L.), field pea (Pisum sativum L), and faba bean (Vicia faba), are able to mobilize soil $P$ through a variety of root mechanisms $[15,16]$.

Recent studies have shown that legumes can regulate soil enzymatic activities more than mineral fertilizers [17]. According to other researchers, legumes such as chickpeas and cowpeas increase phosphatase enzyme activities more than non-legumes $[18,19]$. Soil enzymes play important roles in catalyzing reactions and are associated, directly or indirectly, with nutrient availability and organic matter decomposition [20]. The specific activity of an enzyme is not considered useful in the complete nutrient cycle of soil because it has a particular substrate [21]. Some hydrolytic enzymes (e.g., $\beta$-glucosidase, $\mathrm{N}$-acetyl-glucosaminidase, Leucine-aminopeptidase, and phosphatase), which are related to $\mathrm{C}, \mathrm{N}$, and $\mathrm{P}$ cycles, are more responsible for the soil properties ( $\mathrm{pH}$ and soil organic matter) than other variables. Such enzymes could be valuable as early indicators of biological soil modification [22].

Leguminous plants, especially broad bean (V.faba), Chinese milk vetch (Astragalus sinicus L.), clover (Trifolium repens L.), and hairy vetch ( $V$. villosa L.), have been used in crop rotation systems worldwide [23-25]. Although, $\mathrm{P}$ and $\mathrm{K}$ uptake efficiencies have been reported to be different in various legumes crops [26,27], and the relative knowledge and profound information about leguminous green manures in South China are still unclear. Moreover, less information exists in the literature about the changes in enzymatic activities in response to cultivation of different legume species in the field [28,29]. Green manuring has become a popular practice in South China to improve soil fertility and rice yields at present. The most popular winter green manure is milk vetch, which has traditionally been used for several thousands of years, and most attention has focused on $\mathrm{N}$ utilization.

The main objectives of this study were to (1) evaluate $\mathrm{P}$ and $\mathrm{K}$ uptake capabilities in various winter leguminous green manure species in South China and (2) investigate their ability to affect soil enzyme activity by interacting with soil properties.

\section{Materials and Methods}

\subsection{Experimental Design}

Plot experiments were conducted at two sites in southern China: Nanning City, (Guangxi province), and Qiyang County, (Hunan province), both study sites were selected in the same climatic zones (Sub-tropical) for the cultivation of different winter leguminous green manure species. The meteorological data of the two experimental sites are given in Table 1. Further, the basic soil properties of the two experimental sites are presented in Table 2.

Table 1. The principal meteorological data of the two experimental sites.

\begin{tabular}{ccc}
\hline Particular & Guangxi Site & Hunan Site \\
\hline Geographical coordinate & $20^{\circ} 54^{\prime} \mathrm{N}, 104^{\circ} 29^{\prime} \mathrm{E}$ & $30^{\circ} 08^{\prime} \mathrm{N}, 108^{\circ} 47^{\prime} \mathrm{E}$ \\
Altitude $(\mathrm{m})$ & 99 & 100 \\
$\mathrm{MAT}\left({ }^{\circ} \mathrm{C}\right)$ & 27.7 & 20.2 \\
MAP $(\mathrm{mm})$ & 1750 & 1700 \\
Climatic zone & Subtropical & Subtropical \\
Cropping system & Double paddy rice-green manure & Double paddy rice-green manure \\
\hline
\end{tabular}

Note: MAT means annual temperature. MAP means annual precipitation (Year, 2017).

Six Chinese milk vetch (Astragalus sinicus L.) cultivars (i.e., Minzi No.6, Ningbodaqiao, Wanzi No.1, Xiangzi No.1, Yijiangzi, and Yujiangdaye), and hairy vetch (Vicia villosa L.) and common vetch (Vicia Sativa L.), were used for evaluation. A non-legume plant, ryegrass (Lolium perenne L.), was planted 
as a control. Four replicates were arranged in a randomized complete block design with $1.44 \mathrm{~m}^{2}$ per plot and $51.84 \mathrm{~m}^{2}$ total area in Guangxi site, while $3 \mathrm{~m}^{2}$ per plot with $108 \mathrm{~m}^{2}$ total area was used in Hunan, respectively. No extra fertilizer was added during the experimental period. Chinese milk vetches, hairy vetch, common vetch, and ryegrass cultivars were seeded on 24 October 2017 in Guangxi, and on 20 October 2017 in Hunan, respectively.

Table 2. The basic soil properties of the two experimental sites.

\begin{tabular}{ccc}
\hline Basic Soil Properties & Guangxi Site & Hunan Site \\
\hline $\mathrm{SOM}(\%)$ & 1.2 & 1.0 \\
$\mathrm{TN}\left(\mathrm{g} \mathrm{kg}^{-1}\right)$ & 0.84 & 0.73 \\
$\mathrm{AP}\left(\mathrm{mg} \mathrm{kg}^{-1}\right)$ & 45.5 & 11.2 \\
$\mathrm{AK}\left(\mathrm{mg} \mathrm{kg}^{-1}\right)$ & 134.9 & 122.0 \\
$\mathrm{pH}(1: 2.5)$ & 7.5 & 6.3 \\
$\mathrm{CEC}(\mathrm{cmol} \mathrm{kg}$ & 10.32 \\
Soil Texture & 12.21 & Clay loam \\
Phosphatase $\left(\mathrm{nmol} \mathrm{h}^{-1} \mathrm{~g}^{-1}\right)$ & Silty clay & 128 \\
$\beta$-glucosidase $\left(\mathrm{nmol} \mathrm{h} \mathrm{g}^{-1}\right)$ & 73.2 & 38.2 \\
N-acetyl-glucosaminidase $\left(\mathrm{nmol} \mathrm{h}^{-1} \mathrm{~g}^{-1}\right)$ & 35.0 & 15.2 \\
Leucine-aminopeptidase $\left.\mathrm{nmol} \mathrm{h}^{-1} \mathrm{~g}^{-1}\right)$ & 12.1 & 75.3 \\
\hline
\end{tabular}

Note: SOM (organic matter), TN (total nitrogen), AP (available phosphorus), AK (available potassium), $\mathrm{pH}$ (soil $\mathrm{pH}$ ) and CEC (cation exchange capacity).

\subsection{Sampling}

Soil and plants were sampled on 20 March 2018 in Guangxi and on 12 April 2018 in Hunan, respectively.

The soil samples were collected at a depth of 0-20 cm from each plot and divided into three portions. One portion was immediately stored at $-80^{\circ} \mathrm{C}$ after being carried to the laboratory to analyze the extracellular enzyme activities. The second portion was stored at $-4{ }^{\circ} \mathrm{C}$ for analysis of mineral nitrogen $\left(\mathrm{NH}_{4}{ }^{+}\right.$and $\left.\mathrm{NO}_{3}{ }^{-}\right)$and soil moisture. The third portion was air-dried and passed through a $0.25 \mathrm{~mm}$ sieve for other analyses.

All green manures were harvested at the flowering stage of the milk vetches. The above-ground plant parts were weighted and later were dried in an oven at $65^{\circ} \mathrm{C}$ for 72 hours, crushed, and stored for nutrient analyses.

\subsection{Determination of Soil and Plant}

The contents of $\mathrm{NH}_{4}{ }^{+}$and $\mathrm{NO}_{3}{ }^{-}$in fresh soil sub-samples were extracted with $2 \mathrm{M} \mathrm{KCl}$ (soil: solution 1:10 w:v) and were shaken for 60 minutes to analyze the mineral nitrogen using a continuous flow analyzer (Seal AA3, Norderstedt, Germany) [30]. Soil moisture contents were determined by oven drying at $105^{\circ} \mathrm{C}$ for 48 hours. Total $\mathrm{N}$ contents were analyzed by the Kjeldahl method [31], and soil organic matter by the Walkley Black method [32]. Soil pH was determined at a 1:2.5 soil/water ratio using a pH meter (Mettler Toledo 320-S, Shanghai Bante Instrument Co., Ltd., Shanghai, China). Soil available P (Olsen) was extracted with $0.5 \mathrm{M} \mathrm{NaHCO}_{3}$ and analyzed by using visible light spectroscopy in blue light (UV-VIS spectrophotometer, Model UV-2100, Shimadzu, Kyoto, Japan), following the method in ref. [33]. The exchangeable potassium was analyzed by flame photometry using $5 \mathrm{~g}$ soil and $1 \mathrm{M}$ ammonium acetate (NH4OAc) [34].

The plant's N, P, and K contents were determined by the Kjeldahl digestion method [35], the molybdovanadate method [36], and flame photometry [37], respectively.

\subsection{Soil Enzymatic Activities Measurements}

The activities of four enzymes (i.e., Phosphatase (Phos), $\beta$-glucosidase (BG), $\mathrm{N}$-acetyl-glucosaminidase (NAG), and Leucine-aminopeptidase (LAP)) were measured using a microplate method, as previously described $[38,39]$. For determination, $1 \mathrm{~g}$ of fresh soil was added into a $100 \mathrm{~mL}$ centrifuge tube, and it 
was treated with $50 \mathrm{~mL}$ of $50 \mathrm{mM}$ sodium acetate buffer $\left(\mathrm{C}_{2} \mathrm{H}_{3} \mathrm{NaO}_{2}\right)$ using a polytron homogenizer, then the mixture was poured into a $500 \mathrm{~mL}$ beaker. Additionally, $50 \mathrm{~mL}$ of acetate buffer was used to wash the centrifuge tube and was transferred into the same $500 \mathrm{~mL}$ beaker. The mixture was stirred by using a magnetic stirrer to generate a uniform suspension. The buffer solution, $10 \mu \mathrm{M}$ references, sample suspension, and $200 \mu \mathrm{M}$ substrates (Table 3) were disseminated in a black 96-well microplate to keep the volume and order fixed, following the methods described in ref. [39]. The microplates were covered and incubated in the dark at $25{ }^{\circ} \mathrm{C}$ for $4 \mathrm{~h}$, and fluorescence was quantified using a microplate fluorometer (Scientific Fluoroskan Ascent FL, Thermo) with $365 \mathrm{~nm}$ excitation and $450 \mathrm{~nm}$ emission filters [38]. The activities were expressed in units of $\mathrm{nmol} \mathrm{h}^{-1} \mathrm{~g}^{-1}$.

Table 3. Hydrolytic enzymes evaluated in green manure, their enzyme commission number (EC), and corresponding substrate ( $\mathrm{L}$-DOPA $={ }_{\mathrm{L}}$-3, 4-dihydrox-yphenylalanine, 4-MUB $=4$-methylumbelliferyl).

\begin{tabular}{ccc}
\hline Enzymes & Substrate & EC \\
\hline Phosphatase & 4-MUB-phosphatase & 3.1 .3 .1 \\
$\beta$-Glucosidase & 4-MUB- $\beta$-D-glucosidee & 3.2 .1 .21 \\
N-acetyl-glucosaminidase & 4-MUB-N-acetyl-b-D-glucosaminide & 3.2 .1 .30 \\
Leucine-aminopeptidase & L-Leucine-7-amino-4-methylcoumarin & 3.4 .11 .1 \\
\hline
\end{tabular}

\subsection{Statistical Analyses}

Analysis of variance (ANOVA) using IBM SPSS Statistics Version 20.0 (Corp, Armonk, NY, USA) was carried out to determine the significant difference between the various types of winter legume varieties and their effects on soil properties. Tukey's multiple range tests at $(p<0.05)$ were used to assess the treatment differences. A correlation matrix of the study was based on Pearson's correlation coefficients using ${ }^{*}$ and ${ }^{* *}$ to indicate the $p<0.05$ and $p<0.01$ probability levels, respectively. The enzyme analysis figures were made by using Origin Pro. 9.0 (Northampton, MA, USA). Principal component analysis (PCA) and redundancy analysis (RDA) were carried out by using CONOCO (version 4.5) at a significance level $p<0.05$ to determine the overall relation between different varieties, soil properties, and enzymatic activities.

\section{Results}

\subsection{Plant Biomass and P and K Uptake}

Generally, "above-ground plant biomass" P and K uptakes in leguminous cultivars were higher than ryegrass in both experimental sites, and significant differences were observed for different legumes (Table 4). Moreover, hairy vetch produced the highest above-ground biomass in both sites (i.e., $192.3 \%$ and $155.0 \%$ higher in Guangxi and Hunan, respectively) compared to the control. The percentages of above-ground biomass increased in Guangxi in the following order: Minzi No.6 85.1\%, common vetch 73.9\%, and Wanzi No.159.5\%, respectively, compared to the control. Chinese milk vetch cultivars performed variously, while minimum biomass productions of Hunan cultivars were reported in Ningbodaqiao and ryegrass treatments.

P uptake was also high in hairy vetch (i.e., 260.0\% and 294.0\% higher in Guangxi and Hunan, respectively) compared to the control. The lowest $\mathrm{P}$ uptakes were observed in Xiangzi No.1, only $72.0 \%$ higher than ryegrass in Guangxi, and in Minzi No.6, 9.9\% higher than the control in Hunan. A similar trend was observed in $\mathrm{K}$ uptake, the highest $\mathrm{K}$ uptake was found in hairy vetch with increases of $261.8 \%$ and $131.0 \%$ in Guangxi and Hunan compared to ryegrass treatment. Among the leguminous cultivars, the lowest $\mathrm{K}$ uptakes were found in Ningbodaqiao and Wanzi No.1 at 70.9\% higher than ryegrass in Guangxi. However, ryegrass treatment showed the lowest $\mathrm{K}$ uptake among green manure species in Hunan. Moreover, common vetch had a relatively high ability to uptake P and $\mathrm{K}$. 
Table 4. Plant above-ground biomass $\left(\mathrm{g} \mathrm{m}^{-2}\right)$ and $\mathrm{P}$ and $\mathrm{K}$ uptake $\left(\mathrm{g} \mathrm{m}^{-2}\right)$ in different varieties of leguminous green manures (average \pm standard error)

\begin{tabular}{|c|c|c|c|c|c|c|}
\hline \multirow{2}{*}{ Species } & \multicolumn{3}{|c|}{ Guangxi Site } & \multicolumn{3}{|c|}{ Hunan Site } \\
\hline & Dry Biomass ( $\mathrm{g} \mathrm{m}^{-2}$ ) & P Uptake ( $\left.\mathrm{g} \mathrm{m}^{-2}\right)$ & K Uptake ( $\left.\mathrm{g} \mathrm{m}^{-2}\right)$ & Dry Biomass ( $\mathrm{g} \mathrm{m}^{-2}$ ) & P Uptake $\left(\mathrm{g} \mathrm{m}^{-2}\right)$ & K Uptake ( $\left.\mathrm{g} \mathrm{m}^{-2}\right)$ \\
\hline Ryegrass & $497.5 \pm 45.2 \mathrm{c}$ & $1.55 \pm 0.09 c$ & $12.5 \pm 0.3 c$ & $150.0 \pm 10.0 \mathrm{c}$ & $0.46 \pm 0.04 c$ & $4.56 \pm 0.41 \mathrm{~b}$ \\
\hline Minzi No. 6 & $921.04 \pm 31.3 b$ & $3.39 \pm 0.18 b$ & $29.9 \pm 0.29 b$ & $194.7 \pm 22.2 c$ & $0.50 \pm 0.07 c$ & $7.65 \pm 2.62 \mathrm{ab}$ \\
\hline Ningbodaqiao & $636.4 \pm 51.4 \mathrm{bc}$ & $2.84 \pm 0.38 \mathrm{bc}$ & $21.5 \pm 2.23 b c$ & $152.0 \pm 15.0 \mathrm{c}$ & $0.53 \pm 0.06 c$ & $7.96 \pm 2.06 a b$ \\
\hline Wanzi No. 1 & $793.5 \pm 32.9 \mathrm{bc}$ & $2.84 \pm 0.12 \mathrm{bc}$ & $29.6 \pm 1.85 \mathrm{~b}$ & $206.0 \pm 13.2 c$ & $0.71 \pm 0.03 c$ & $5.99 \pm 0.54 \mathrm{ab}$ \\
\hline Xiangzi No.1 & $636.2 \pm 27.0 \mathrm{bc}$ & $2.66 \pm 0.19 b c$ & $22.8 \pm 1.62 \mathrm{bc}$ & $208.0 \pm 13.1 \mathrm{c}$ & $0.70 \pm 0.06 c$ & $7.07 \pm 0.78 \mathrm{ab}$ \\
\hline Yijiangzi & $652.5 \pm 88.6 \mathrm{bc}$ & $2.76 \pm 0.22 b c$ & $24.3 \pm 2.99 \mathrm{bc}$ & $192 \pm 4.62 c$ & $0.62 \pm 0.08 c$ & $6.20 \pm 0.33 \mathrm{ab}$ \\
\hline Yujiangdaye & $920.5 \pm 94.6 \mathrm{~b}$ & $3.14 \pm 0.39 b$ & $33.8 \pm 3.66 \mathrm{ab}$ & $172 \pm 8.33 c$ & $0.72 \pm 0.05 c$ & $5.14 \pm 0.40 a b$ \\
\hline Hairy vetch & $1454.2 \pm 165.8 \mathrm{a}$ & $5.56 \pm 0.60 \mathrm{a}$ & $45.5 \pm 5.22 \mathrm{a}$ & $382.5 \pm 27.8 \mathrm{a}$ & $1.79 \pm 0.13 \mathrm{a}$ & $10.5 \pm 0.65 \mathrm{a}$ \\
\hline Common vetch & $865.1 \pm 37.2 \mathrm{~b}$ & $3.05 \pm 0.31 b$ & $30.8 \pm 1.70 b$ & $295.0 \pm 15.5 b$ & $1.16 \pm 0.17 b$ & $9.97 \pm 0.62 \mathrm{ab}$ \\
\hline
\end{tabular}

Ryegrass planted as a control, six Chinese milk vetch varieties, and two other legume species (hairy vetch and common vetch) are reported. The small letter indicates significant differences at $(p<0.05)$ using Tukey's multiple range tests. 


\subsection{Effects of Winter Legume Species on Soil P and $\mathrm{K}$}

Changes were recorded in available $\mathrm{P}$ and $\mathrm{K}$ in soil among the studied leguminous varieties in both experimental sites (Table 5). Soil P contents in different treatments were higher than ryegrass and increased in the following order: Wanzi No.1 by $41.2 \%$, Yijiangzi by $29.3 \%$, and common vetch by $25.5 \%$, respectively, higher than ryegrass. The lowest soil $\mathrm{P}$ was observed in Xiangzi No.1 among the tested leguminous varieties. Soil $\mathrm{K}$ increased in Yujiangdaye, common vetch, and Wanzi No.1 by $59.2 \%, 58.6 \%$, and $46.7 \%$, respectively, higher than the control. In Hunan, soil P and K contents were significantly increased in Ningbodaqiao by $30.6 \%$ and Yujiangdaye by $50.7 \%$ compared to the ryegrass, while $\mathrm{P}$ and $\mathrm{K}$ content decreased in Minzi No.1 by $53.5 \%$ and hairy vetch by $5.8 \%$ in the Hunan site.

Table 5. Influence of green manure on available phosphorus and potassium in soil (average \pm standard error).

\begin{tabular}{|c|c|c|c|c|}
\hline \multirow{2}{*}{ Species } & \multicolumn{2}{|c|}{ Guangxi Site } & \multicolumn{2}{|c|}{ Hunan Site } \\
\hline & $P\left(\mathrm{mg} \mathrm{kg}^{-1}\right)$ & $\mathrm{K}\left(\mathrm{mg} \mathrm{kg}^{-1}\right)$ & $P\left(\mathrm{mg} \mathrm{kg}^{-1}\right)$ & $\mathrm{K}\left(\mathrm{mg} \mathrm{kg}^{-1}\right)$ \\
\hline Ryegrass & $48.3 \pm 1.79 c$ & $103.4 \pm 3.02 \mathrm{~d}$ & $13.6 \pm 0.50 \mathrm{bc}$ & $110.3 \pm 0.72 b$ \\
\hline Minzi No. 6 & $50.5 \pm 3.09 c$ & $124.6 \pm 3.09 \mathrm{~cd}$ & $8.84 \pm 1.47 \mathrm{~d}$ & $114.1 \pm 4.20 \mathrm{~b}$ \\
\hline Ningbodaqiao & $55.0 \pm 1.91 \mathrm{bc}$ & $113.0 \pm 1.91 \mathrm{de}$ & $17.7 \pm 0.96 \mathrm{a}$ & $110.4 \pm 7.89 b$ \\
\hline Wanzi No. 1 & $68.3 \pm 1.13 \mathrm{a}$ & $151.7 \pm 1.13 \mathrm{ab}$ & $13.7 \pm 0.43 \mathrm{abc}$ & $127.9 \pm 7.93 b$ \\
\hline Xiangzi No. 1 & $50.3 \pm 2.13 c$ & $130.7 \pm 2.13 \mathrm{bcd}$ & $10.4 \pm 1.31 \mathrm{~cd}$ & $127.5 \pm 13.1 b$ \\
\hline Yijiangzi & $62.5 \pm 2.13 \mathrm{ab}$ & $138.5 \pm 2.81 \mathrm{abc}$ & $14.6 \pm 0.70 \mathrm{ab}$ & $121.9 \pm 5.07 b$ \\
\hline Yujiangdaye & $56.1 \pm 0.34 \mathrm{bc}$ & $164.7 \pm 0.34 \mathrm{a}$ & $14.6 \pm 0.58 \mathrm{~b}$ & $166.2 \pm 7.97 \mathrm{a}$ \\
\hline Hairy vetch & $55.7 \pm 0.82 \mathrm{bc}$ & $136.7 \pm 0.82 \mathrm{abc}$ & $13.7 \pm 0.61 b$ & $103.8 \pm 1.00 \mathrm{~b}$ \\
\hline Common vetch & $60.7 \pm 3.07 \mathrm{bc}$ & $164.0 \pm 3.07 \mathrm{a}$ & $15.0 \pm 0.08 \mathrm{ab}$ & $117.2 \pm 5.74 b$ \\
\hline
\end{tabular}

Ryegrass (control), six Chinese milk vetch varieties, and two other legume species (hairy vetch and common vetch) are reported, and different small letters indicate significant differences at $(p<0.05)$ using Tukey's multiple range tests.

\subsection{Soil Enzymatic Activities}

"Various species of green manure" showed significant effects $(p<0.05)$ on phosphatase (Phos), $\beta$-glucosidase (BG), N-acetylglucosaminidase (NAG), and leucine-aminopeptidase (LAP) activities in the Guangxi site (Figure 1). They highly depended on different species at both experimental sites. The highest phosphatase and LAP activities were found in hairy vetch (i.e. $87.0 \%$ and $163.8 \%$ higher than the ryegrass treatment, respectively). The lowest phosphatase activity was in Xiangzi No.1 treatment, only $23.3 \%$ higher than the ryegrass, while the lowest LAP activity was reported in the control treatment (Figure 1A,D). The highest $\beta$-glucosidase activity was demonstrated in Yijiangzi (143.4\% higher), while the lowest activity was in Minzi No.6 (12.2\%) compared to the control. The NAG activity was high in Yujiangdaye (283.3\% higher), whereas the lowest NAG activity was in Yijiangzi at only $4.3 \%$ compared to the control.

More obvious modifications were recorded for the enzymatic activities in the Hunan site (Figure 2). Xiangzi No.1 stimulated the activities of BG (786.0\% higher), phosphatase (591.0\% higher), LAP (477.5\% higher), and NAG (352.6\% higher), respectively, compared to the control. Conversely, Ningbodaqiao had smaller effects on the activities of BG (106.3\% higher) and NAG (32.6\% higher), respectively, when compared to the control. Minor changes in phosphatase activity were also seen in Ningbodaqiao (only 5.3\% higher compared to the control). Common vetch showed a 9.6\% higher LAP activity compared to the control. 

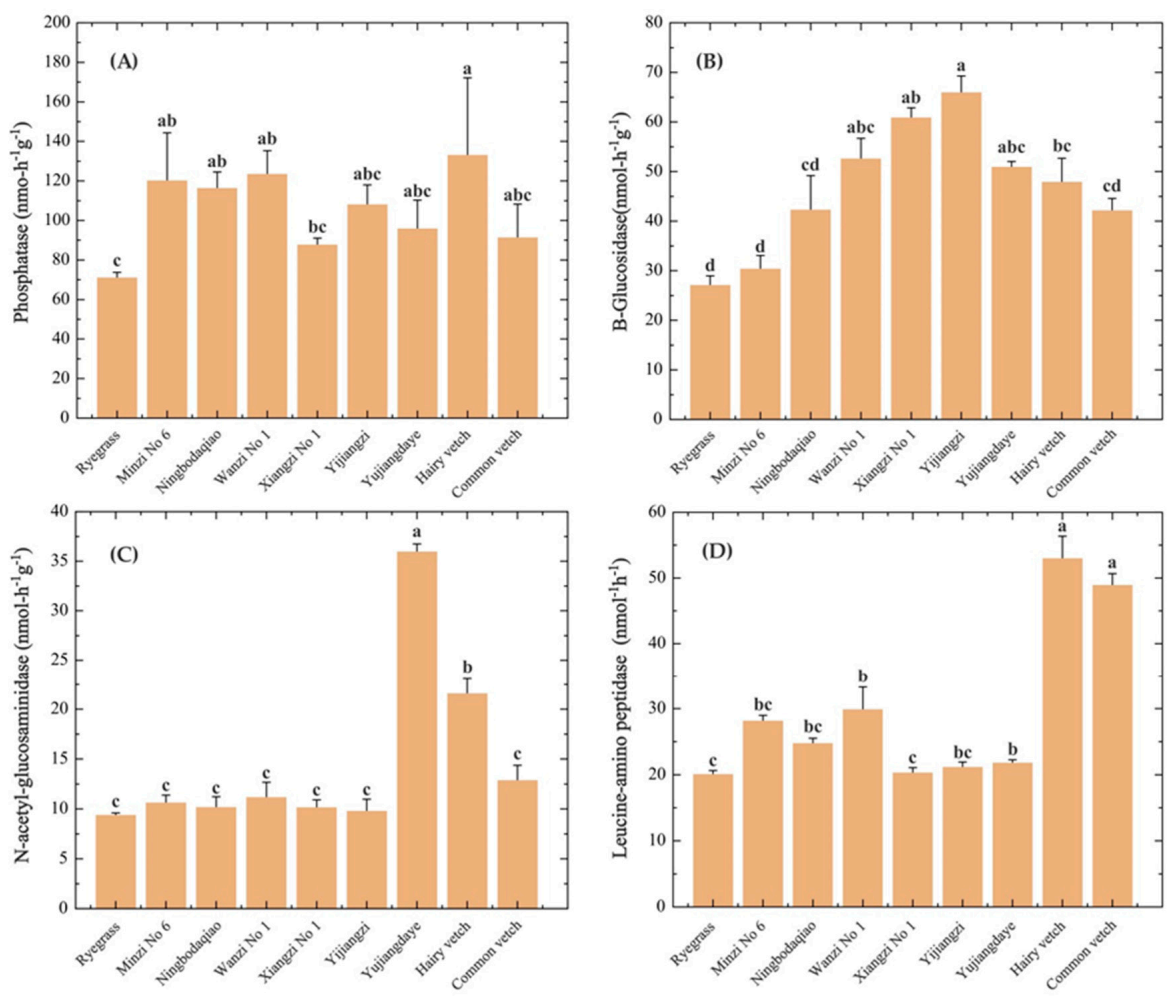

Figure 1. Effects of green manure species on enzyme activities: phosphatase (A), $\beta$-glucosidase (B), $\mathrm{N}$-acetylglucosaminidase (C), and leucine-aminopeptidase (D) in Guangxi, China. Different letters show significant influences $(p<0.05)$ using Tukey's multiple range tests.
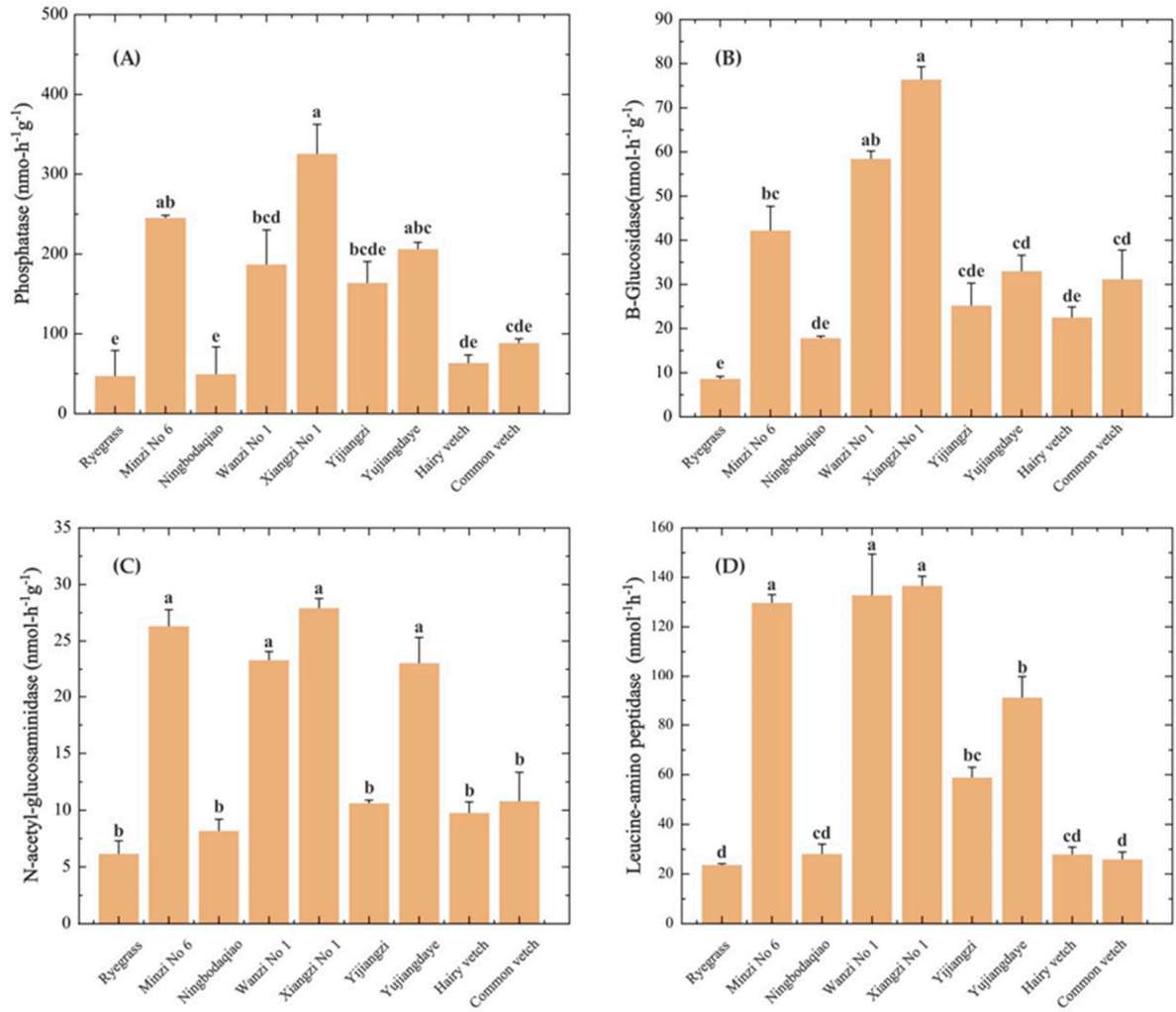

Figure 2. Effects of green manure species on enzyme activities: phosphatase (A), $\beta$-glucosidase (B), $\mathrm{N}$-acetylglucosaminidase (C), and leucine-aminopeptidase (D) in the Hunan site. Different letters show significant influences $(p<0.05)$ using Tukey's multiple range tests. 


\subsection{Correlation between P, K Uptake, and Soil Enzymes}

Based on Pearson's correlation $(r)$ analysis, $\mathrm{P}$ and $\mathrm{K}$ uptake greatly correlated with phosphatase, $\mathrm{N}$-acetylglucosaminidase, and leucine-aminopeptidase activities $\left(r=0.357^{*}, 0.333^{*}\right.$ and $0.631^{* *}$, respectively) and was not significantly related with $\beta$-glucosidase enzyme activity in Guangxi (Table 6). Non-significant relationships were observed in Hunan among P and K uptake and soil enzymatic activities.

\subsection{Correlation among Soil $p H$ and Soil $P, K$}

However, Pearson's correlation $(r)$ analysis showed non-significant relationship among soil $\mathrm{pH}$ and available $P$ in both experimental sites (Table 7), whereas a negative, significant correlation was noted between soil $\mathrm{pH}\left(r=-0.369^{*}\right)$ and $\mathrm{K}$ contents in the Hunan site.

\subsection{Correlation between Soil Enzymes and Soil Properties}

The redundancy analysis (RDA) showed that the first and second axes explained $23.1 \%$ and $13.5 \%$ of the variation for enzyme activities and soil properties in Guangxi (Figure 3A), while both canonical axes described $84.7 \%$ and $77.9 \%$ of the total modification between enzymatic activities and soil properties. The enzyme activities were significantly correlated with SOM ( $\mathrm{F}=5.8, p<0.002)$, $\mathrm{TN}(\mathrm{F}=5.7, p<0.002), \mathrm{NO}_{3}{ }^{-}(\mathrm{F}=8.3, p<0.002)$, and $\mathrm{AK}(\mathrm{F}=4.1, p<0.006)$. The right lower corner of the first axis was related to the N-cycling enzymes. The NAG activity was strongly correlated with exchangeable $\mathrm{K}$ and negatively correlated with SOM. The upper right corner showed that the $\mathrm{C}$-cycling enzyme BG was associated with soil $\mathrm{TN}, \mathrm{NO}_{3}{ }^{-}$, and $\mathrm{AP}$.
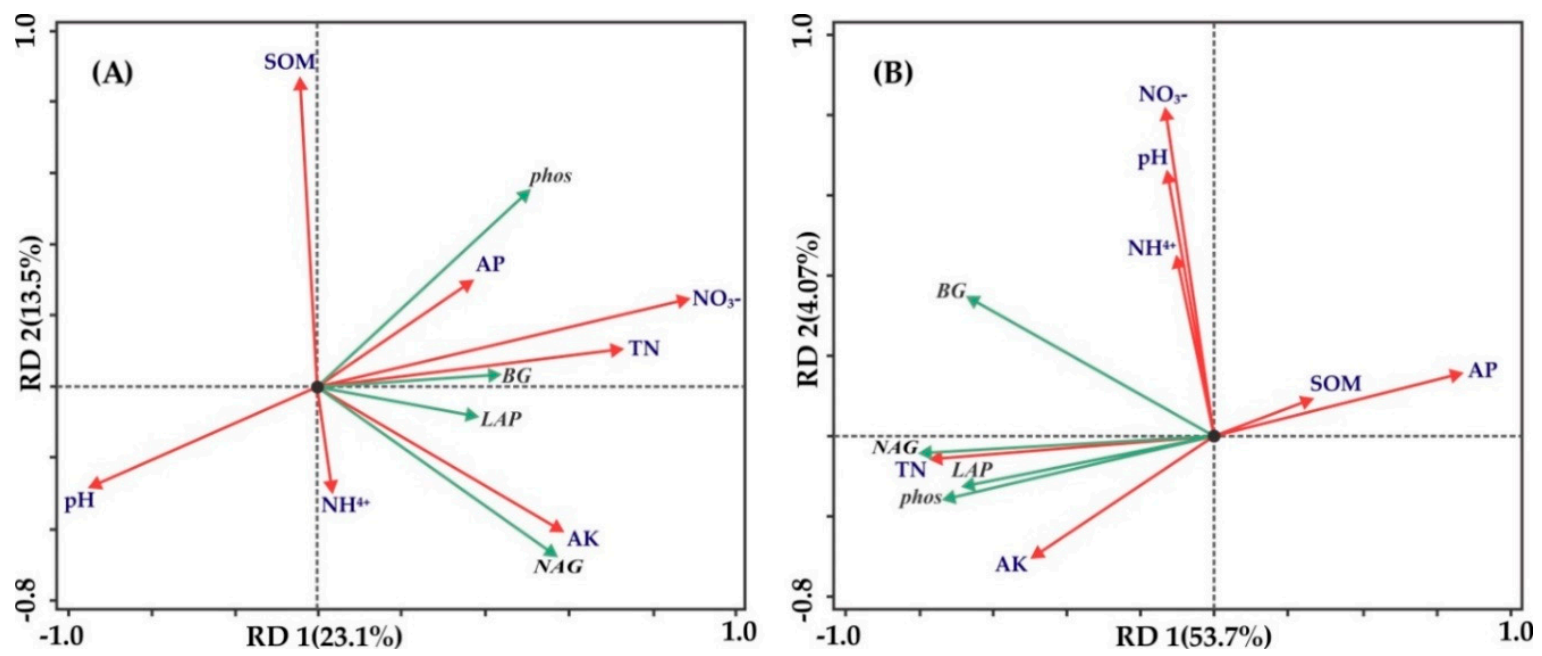

Figure 3. Redundancy analysis (RDA) indicates the correlation between soil enzyme activities and soil properties, (A) Guangxi, (B) Hunan site. Note: Phos (phosphatase), BG ( $\beta$-glucosidase), NAG (N-acetylglucosaminidase) and LAP (leucine-aminopeptidase) are significantly correlated with soil properties: SOM (organic matter), TN (total nitrogen), $\mathrm{NH}_{4}{ }^{+}$and $\mathrm{NO}_{3}{ }^{-}$(mineral nitrogen), $\mathrm{AP}$ (available phosphorus) and AK (available potassium).

According to the RDA analysis, soil enzymes showed significant correlations with three soil properties in Hunan site (Figure 3B), and the first (RD1) and second axes (RD2) explained 53.7\% and $4.01 \%$ of the total variation. Soil enzymes showed a significant relationship with available $\mathrm{P}(\mathrm{F}=10.9$, $p<0.002), \mathrm{TN}(\mathrm{F}=16.2, p<0.002)$, and available $\mathrm{K}(\mathrm{F}=5.6, p<0.024)$, respectively, whereas, available soil $P$ showed a significant, negative relationship with phosphatase enzymes. 
Table 6. Pearson's correlation $(r)$ between P, K uptake, and soil enzymatic activities.

\begin{tabular}{|c|c|c|c|c|c|c|c|c|c|c|}
\hline \multirow{2}{*}{ Parameters } & \multicolumn{5}{|c|}{ Guangxi Site } & \multicolumn{5}{|c|}{ Hunan Site } \\
\hline & K uptake & Phos & BG & NAG & LAP & K uptake & Phos & BG & NAG & LAP \\
\hline P uptake & $0.909 * *$ & 0.357 * & 0.184 & 0.333 * & $0.631^{* *}$ & $0.605^{* *}$ & 0.225 & -0.081 & -0.214 & -0.316 \\
\hline K uptake & 1 & 0.321 & 0.245 & $0.479 * *$ & $0.641^{* *}$ & 1 & 0.183 & -0.002 & -0.156 & -0.204 \\
\hline Phos & & 1 & 0.044 & 0.069 & $0.344^{* *}$ & & 1 & $0.754^{* *}$ & $0.839 *$ & $0.832^{* *}$ \\
\hline BG & & & 1 & 0.088 & -0.078 & & & 1 & $0.785^{* *}$ & $0.802 * *$ \\
\hline NAG & & & & 1 & 0.133 & & & & 1 & $0.891^{* *}$ \\
\hline LAP & & & & & 1 & & & & & 1 \\
\hline
\end{tabular}

Note: Phos (phosphatase), BG ( $\beta$-glocosidase), NAG (N-acetylglucosaminidase), and LAP (leucine-aminopeptidase). ${ }^{*}, *$ significant at $p<0.05, p<0.01$, respectively.

Table 7. Pearson's correlation coefficient $(r)$ between soil $\mathrm{pH}$ and available phosphorus and potassium.

\begin{tabular}{|c|c|c|c|c|c|c|}
\hline \multirow{2}{*}{ Parameters } & \multicolumn{3}{|c|}{ Guangxi Site } & \multicolumn{3}{|c|}{ Hunan Site } \\
\hline & $\mathrm{pH}$ & $\mathrm{AP}\left(\mathrm{mg} \mathrm{kg}{ }^{-1}\right)$ & $\mathrm{AK}\left(\mathrm{mg} \mathrm{kg}{ }^{-1}\right)$ & $\mathrm{pH}$ & $\mathrm{AP}\left(\mathrm{mg} \mathrm{kg}{ }^{-1}\right)$ & $\mathrm{AK}\left(\mathrm{mg} \mathrm{kg} \mathrm{k}^{-1}\right)$ \\
\hline $\mathrm{pH}$ & 1 & 0.02 & -0.323 & 1 & -0.072 & -0.369 * \\
\hline $\mathrm{AP}\left(\mathrm{mg} \mathrm{kg}^{-1}\right)$ & & 1 & $0.359 *$ & & 1 & 0.054 \\
\hline $\left.\mathrm{AK} \mathrm{mg} \mathrm{kg}{ }^{-1}\right)$ & & & 1 & & & 1 \\
\hline
\end{tabular}

AP (available phosphorus), AK (available potassium), ${ }^{*}$ significant at $p<0.05$. 


\subsection{Correlation between Legumes and Soil Properties}

The Principal Component Analysis (PCA) showed a clear difference between various legumes and soil properties (Figure 4). The contents of $\mathrm{TN}, \mathrm{NO}_{3}{ }^{-}$, soil available $\mathrm{P}$ and available $\mathrm{K}$ were the most different among the different legumes, followed by hairy vetch, Yijiangzi, Wanzi, and Ningbodaqiao. Maximum SOM was related to Wanzi No.1 and Xiangzi No.1 in Guangxi. In Hunan, the first axis contributed to $87.3 \%$ of the variation in different varieties and soil properties (Figure $4 \mathrm{~B}$ ). The highest available $\mathrm{P}, \mathrm{TN}$, and AK in soil were shown in Ningbodaqiao, Wanzi No.1, and Yujiangdaye treatments.

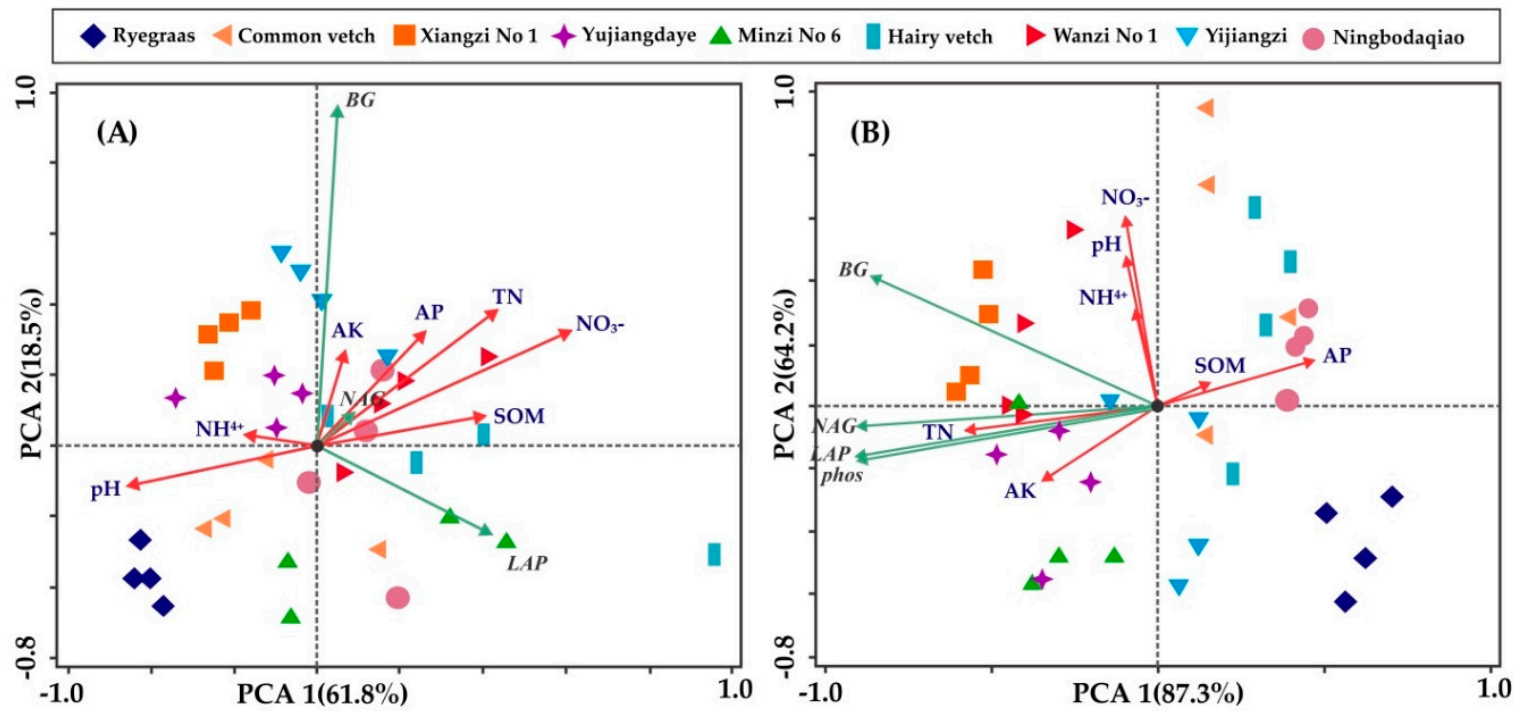

Figure 4. Principal component analysis (PCA) showed relationship between legumes and soil properties: (A) Guangxi, (B) Hunan. Note: Phos (phosphatase), BG ( $\beta$-glucosidase), NAG (N-acetylglucosaminidase) and LAP (leucine-aminopeptidase) are significantly correlated with soil properties, $\mathrm{SOM}$ (organic matter), $\mathrm{TN}$ (total nitrogen), $\mathrm{NH}_{4}{ }^{+}$and $\mathrm{NO}_{3}{ }^{-}$(mineral nitrogen), $\mathrm{AP}$ (available phosphorus) and AK (available potassium).

\section{Discussion}

\subsection{Plant. P and K Uptake and Soil Nutrient Availability}

The present study compared the P and K uptake efficiencies in different legume species. The dry biomass accumulation and the capability to obtain $\mathrm{P}$ and $\mathrm{K}$ from the soil varied significantly among species. Maximum $\mathrm{P}$ and $\mathrm{K}$ uptake abilities were observed in hairy vetch at both sites (Table 4). Our results agreed with previous work, where the morphological traits and a greater biomass relates to a high nutrient uptake in hairy vetch [40]. Above-ground biomass and $\mathrm{P}$ and $\mathrm{K}$ uptake by mass flow is important, which occurs in the roots and helps in the transportation of $\mathrm{P}$ and $\mathrm{K}$ to the lateral parts [41,42].

According to the current hypothesis, changes can be observed in available $\mathrm{P}$ and $\mathrm{K}$ in soil after cultivation of different legume species. The results revealed that the P content significantly increased in Guangxi (Table 5), while both varieties (Ningbodaqiao and common vetch) greatly improved available soil $\mathrm{P}$ in Hunan. This study highlighted that legumes like M. sativa, T. pratense, and Lupinus were also found to have positive influences on P status $[43,44]$. Legumes can mobilize $P$, relative to their growth period, because P-solubilizing compounds are secreted in the rhizosphere [45]. Leguminous crops during their growth period showed a key impact on soil K availability in both sites (Table 5). Similarities were found in another study on green manure crops, where K availability was increased, which could be associated with the extensive root systems of leguminous crops [46]. The extensive root system of legumes is beneficial to improve the physical condition of the soil because they have the ability to release organic acids from their roots, which may increase K availability in soil [47]. 


\subsection{Effect of Legume Species on Enzymatic Activities}

Legume plants can stimulate microbial proliferation, which could be the cause of the increase in soil enzyme activity. The data show significant changes in the activities of enzymes under different kinds of winter legume varieties. These crops can enhance the catalysts to support the microbial population and promote their growth [48]. The present study showed that phosphatase activities were enhanced in both experimental sites (Figures 1 and 2). Similar results were found, where higher phosphatase levels were observed in broad bean (V. faba) and vetches (Vicieae) in a separate field study [49]. However, phosphatase activity at the Hunan site was higher than that at the Guangxi site. A higher phosphatase activity in Hunan could be due to the soil $\mathrm{pH}$ range. A previous study reported that greater phosphate activities were found in acidic to neutral soil [50]. Each species in this study had a unique specialization in morphological traits. However, higher phosphate activity may depend on different factors, for example, high density of root hairs of legumes facilitated the phosphatase activity due to root hairs assisting in the release of phosphate [51]. In addition to the release of organic acids, cluster roots are also efficient at releasing phosphatase [52]. Legume roots release phosphatase to intensify the solubilization and remobilization of phosphate, thus influencing the ability of the plant to survive in phosphorus-stressed conditions [53]. Yijiangzi increased the activity of the BG enzyme in Guangxi (Figure 1), and Xiangzi No.1 promoted it in Hunan. These findings are also supported by other studies, showing that $T$. pratense $\mathrm{L}$ and B. napus leguminous species produced more $\beta$-glucosidase activity $[54,55]$. Green manure add substrate to the soil microorganisms not only at the phase of their incorporation, but also throughout their growth period as well, e.g. through root exudation, root turnover and symbiosis with mycorrhiza [56]. This could be associated with the behaviour of the carbon cycle that catalyzes the hydrolysis of sucrose into glucose and fructose, which activates the microbial population and increases $\beta$-glucosidase activity $[57,58]$. The results also report that there were significant alterations in NAG and LAP activities. The rate of increasing $\mathrm{N}$ in the soil through leguminous plants not only involves the $\mathrm{N}$-cycle but also increases enzyme activities [59]. The activity of soil enzymes is the main factor in $\mathrm{N}$ transformation in soil, and changes in the activities of $\mathrm{N}$-degrading enzymes will affect the availability of $\mathrm{N}$ in soil [60].

\subsection{Relationship among P and K Uptake, Soil Properties, and Enzymatic Activities}

According to Pearson's correlation coefficient, $\mathrm{P}$ and $\mathrm{K}$ uptake was strongly related to hydrolytic enzymes in Guangxi (Table 6). Phosphatase, $\beta$-glucosidase, $\mathrm{N}$-acetylglucosaminidase, and Leucine-aminopeptidase activities are responsible for the degradation of phosphoric acid into phosphate, carbohydrates into starch, glycogen chitin into cellulose, and proteins into amino acids [61]. Studies concluded that $\mathrm{P}$ and $\mathrm{K}$ uptake was associated with legume species and phosphatase enzymes [62]. This could be the reason that phosphatase activity is associated with mineralization of $\mathrm{P}$ in soils and plays an important role in P cycling that improves plant growth [63]. Our study reported that phosphatase activity was significantly positively related to SOM, and the NAG enzyme was negatively correlated with SOM in Guangxi. The soil's enzymatic activities can act as indicators to identify soil organic matter. Whereas in the some cases, enzymatic activities that interact with the microbial community can be used as indicators of potential SOM decomposition, which leads to an increase in potential nutrient availability [64]. The current study did not find any significant interaction among soil pH with soil $\mathrm{P}$ in both experimental sites (Table 7). In this study, soil pH ranges were noted to be slightly acidic in (Hunan) and slightly alkaline in (Guangxi). Most of the nutrients are available in slightly acidic to slightly alkaline soil ( $\mathrm{pH} 6.5$ to 7.5) [65]. It could be that the P solubilization mechanism requires a different amount of time, while the $\mathrm{pH}$ changes immediately in soil, which may not affect the P solubility [66]. While soil $\mathrm{pH}$ was significantly, negatively related with soil $\mathrm{K}$ content in the Hunan site (Table 7), this negative correlation might be due to the acidic soil of the Hunan site. Similarities were noted in another study, which also showed a significantly negative interaction between soil pH and $\mathrm{K}$ content [67]. Due to $\mathrm{K}$ being a basic cation, the $\mathrm{K}$ content changed to available 
$\mathrm{K}$ with the increase in soil $\mathrm{pH}$ from slightly acidic to strongly acidic in the chemical reaction. Mostly, cations were leached in acidic conditions $[65,68]$.

The present study measured soil enzyme activities, which provided integrated effects for the changes in soil properties under different legume treatments. The redundancy analysis (RDA) indicated a significant, positive correlation among soil enzymatic activities and soil properties in both experimental sites (Figure 3). However, C- and N-cycling enzymes, BG and NAG, and LAP activities were correlated with $\mathrm{NH}_{4}{ }^{+}$and $\mathrm{NO}_{3}{ }^{-}$. Some researchers addressed how $\mathrm{C}$-cycle enzymes contribute to alterations in the substrate availability of essential nutrients, and the activities of enzymes are closely related to the changes in chemical properties $[69,70]$. The $\mathrm{N}$-related enzymes might be the sources to break down the organic $\mathrm{N}$ compounds through their action, which decreases $\mathrm{N}$ limitations [71]. The principle component analysis (PCA) showed that Legumes were related to the soil properties in the current study, whereas another study showed green manure played a vital role in improving the soil quality [14]. The soil properties were affected by leguminous species because of their shoot and root characteristics, which were related with the high nutrient concentration under low-fertility conditions [72].

The present study indicated that the phosphate activity had no obvious association with available $P$ in soil in Guangxi (Figure 3). Usually, the correlation between phosphatase activity and available phosphorus in the soil environment is complicated. When no relationship is found, there could be other factors that influence the activity of enzymes [73]. In contrast, the P-cycling phosphate enzyme was significantly, negatively related to available P in soil in Hunan (Figure 3). This negative correlation between available $\mathrm{P}$ and phosphatase enzyme activity was also documented in a previous study [73]. A higher phosphatase activity could be associated with the basic transformation of $\mathrm{P}$, mainly originating from the hydrolysis of esters and anhydrides of phosphoric acid $\left(\mathrm{H}_{3} \mathrm{PO}_{4}\right)$. The microbial biomass of soil would be the most important factor for measuring enzymatic activities in an eco-system, which might be associated with more enhanced enzyme metabolic activities [63,74].

\section{Conclusions}

Our results emphasize that hairy vetch has the highest $\mathrm{P}$ and $\mathrm{K}$ uptake capacities, and this was related to the highest biomass and most prominent root morphological mechanisms in both experimental sites. This study revealed that winter green manure that contains hairy vetch might be a potential choice to improve management of $\mathrm{P}$ and $\mathrm{K}$ in paddy soil in South China, which is conducive to ongoing crop cultivation and agricultural practices. Planting of green manure can also reduce the fertilizer needed for upcoming crop production. Further research needs to clarify the contribution of green manure crops in the soil microbial community structure, and studies into soil enzyme activities to find time scale changes during the cultivation period at different zones and stages, are required to explain the mechanisms behind their correlations.

Author Contributions: Conceptualization, W.C.; Data curation, F.S.; Formal analysis, F.S.; Funding acquisition, W.C.; Investigation, F.S.; Methodology, F.S. and W.C.; Project administration, W.C.; Software, F.S.; Supervision, W.C.; Validation, F.S.; Visualization, F.S.; Writing-original draft, F.S.; Writing-review \& editing, J.B., S.G., L.Y. and G.Z.

Funding: This work was supported by China Agriculture Research System - Green Manure; the Virtual Joint Nitrogen Centre (N-Circle; Grant number BB/N013484/1); Science and Technology Innovation Project of Chinese Academy of Agricultural Sciences (2013-2017); and Chinese Outstanding Talents Program in Agricultural Science.

Conflicts of Interest: The authors declare no conflict of interest.

\section{References}

1. Balemi, T.; Negisho, K. Management of soil phosphorus and plant adaptation mechanisms to phosphorus stress for sustainable crop production: A review. J. Soil Sci. Plant Nutr. 2012, 12, 547-561. [CrossRef]

2. Wang, M.; Zheng, Q.; Shen, Q.; Guo, S. The critical role of potassium in plant stress response. Int. J. Mol. Sci. 2013, 14, 7370-7390. [CrossRef] [PubMed] 
3. Cordell, D.; Rosemarin, A.; Schröder, J.J.; Smit, A.L. Towards global phosphorus security: A systems framework for phosphorus recovery and reuse options. Chemosphere 2011, 84, 747-758. [CrossRef] [PubMed]

4. Vance, C.P.; Uhde-Stone, C.; Allan, D.L. Phosphorus acquisition and use: Critical adaptations by plants for securing a nonrenewable resource. New Phytol. 2003, 157, 423-447. [CrossRef]

5. Meena, B.; Fagodiya, R.K.; Kaledhonkar, M.J.; Meena, R.S. Legumes for Soil Health and Sustainable Management; Springer: Berlin/Heidelberg, Germany, 2018.

6. Richardson, A.E.; Hocking, P.J.; Simpson, R.J.; George, T.S. Plant mechanisms to optimise access to soil phosphorus. Crop. Pasture Sci. 2009, 60, 124. [CrossRef]

7. Suriyagoda, L.D.B.; Ryan, M.H.; Renton, M.; Lambers, H. Adaptive shoot and root responses collectively enhance growth at optimum temperature and limited phosphorus supply of three herbaceous legume species. Ann. Bot. 2012, 110, 959-968. [CrossRef]

8. Qi, Z.; Spalding, E.P. Protection of plasma membrane $\mathrm{K}^{+}$transport by the salt overly sensitive1 $\mathrm{Na}+-\mathrm{H}+$ antiporter during salinity stress. Plant Physiol. 2004, 136, 2548-2555. [CrossRef]

9. Smith, F.A.; Jansa, J.; Finlay, R.; Smith, S.E. Role of Mycorrhizal Symbioses in Phosphorus Cycling. In Phosphorus in Action; Springer: Berlin/Heidelberg, Germany, 2011.

10. Zanatta, J.A.; Bayer, C.; Dieckow, J.; Vieira, F.C.B.; Mielniczuk, J. Soil organic carbon accumulation and carbon costs related to tillage, cropping systems and nitrogen fertilization in a subtropical Acrisol. Soil Tillage Res. 2007, 94, 510-519. [CrossRef]

11. Ntakirutimana, L.; Li, F.; Huang, X.; Wang, S.; Yin, C. Green manure planting incentive measures of local authorities and farmers' perceptions of the utilization of rotation fallow for sustainable agriculture in Guangxi, China. Sustainability 2019, 11, 2723. [CrossRef]

12. Requejo, M.I.; Eichler-Löbermann, B. Organic and inorganic phosphorus forms in soil as affected by long-term application of organic amendments. Nutr. Cycl. Agroecosystems 2014, 100, 245-255. [CrossRef]

13. Sulieman, S.; Ha, C.V.; Schulze, J.; Tran, L.S.P. Growth and nodulation of symbiotic Medicago truncatula at different levels of phosphorus availability. J. Exp. Bot. 2013, 64, 2701-2712. [CrossRef]

14. Fageria, N.K.; Baligar, V.C.; Bailey, B.A. Role of Cover Crops in Improving Soil and Row Crop Productivity. Commun. Soil Sci. Plant Anal. 2005, 36, 2733-2757. [CrossRef]

15. Li, L.; Tang, C.; Rengel, Z.; Zhang, F. Chickpea facilitates phosphorus uptake by intercropped wheat from an organic phosphorus source. Plant Soil. 2003, 248, 297-303. [CrossRef]

16. Nuruzzaman, M.; Lambers, H.; Bolland, M.D.A.; Veneklaas, E.J. Phosphorus benefits of different legume crops to subsequent wheat grown in different soils of Western Australia. Plant Soil. 2005, 271, 175-187. [CrossRef]

17. N'Dayegamiye, A.; Tran, T. Sen Effects of green manures on soil organic matter and wheat yields and $\mathrm{N}$ nutrition. Can. J. Soil Sci. 2001, 81,371-382. [CrossRef]

18. Liu, Y.; Mi, G.; Chen, F.; Zhang, J.; Zhang, F. Rhizosphere effect and root growth of two maize (Zea mays L.) genotypes with contrasting P efficiency at low P availability. Plant Sci. 2004, 167, 217-223. [CrossRef]

19. Maseko, S.T.; Dakora, F.D. Rhizosphere acid and alkaline phosphatase activity as a marker of $P$ nutrition in nodulated Cyclopia and Aspalathus species in the Cape fynbos of South Africa. South Afr. J. Bot. 2013, 89, 289-295. [CrossRef]

20. Chodak, M.; Niklińska, M. Development of microbial biomass and enzyme activities in mine soils. Pol. J. Env. Stud. 2012, 21, 569-577.

21. Nannipieri, P.; Giagnoni, L.; Renella, G.; Puglisi, E.; Ceccanti, B.; Masciandaro, G.; Fornasier, F.; Moscatelli, M.C.; Marinari, S. Soil enzymology: Classical and molecular approaches. Biol. Fertil. Soils 2012, 48, 743-762. [CrossRef]

22. Caravaca, F.; Masciandaro, G.; Ceccanti, B. Land use in relation to soil chemical and biochemical properties in a semiarid Mediterranean environment. Soil Tillage Res. 2002, 68, 23-30. [CrossRef]

23. Kim, S.Y.; Lee, C.H.; Gutierrez, J.; Kim, P.J. Contribution of winter cover crop amendments on global warming potential in rice paddy soil during cultivation. Plant Soil. 2013, 366, 273-286. [CrossRef]

24. Melero, S.; Porras, J.C.R.; Herencia, J.F.; Madejon, E. Chemical and biochemical properties in a silty loam soil under conventional and organic management. Soil Tillage Res. 2006, 90, 162-170. [CrossRef]

25. Berland, R.; Kjersti, A.; Azzaroli, M.; Riley, H.; Pommeresche, R.; Thorup-kristensen, K.; Hansen, S. Effects of green manure herbage management and its digestate from biogas production on barley yield, N recovery, soil structure and earthworm populations. Eur. J. Agron. 2014, 52, 90-102. 
26. Fageria, N.K.; Gheyi, H.R.; Carvalho, M.C.S.; Moreira, A.; Gheyi, H.R.; Carvalho, M.C.S.; Moreira, A. Root growth, nutrient uptake and use efficiency by roots of tropical legume cover crops as influenced by phosphorus fertilization. J. Plant Nutr. 2016, 39, 781-792. [CrossRef]

27. Tibbett, M.; Cawthray, G. Variation in morphological and physiological parameters in herbaceous perennial legumes in response to phosphorus. Plant Soil. 2014, 331, 241-255.

28. Eichler, B.; Caus, M.; Schnug, E.; Köppen, D. Soil acid and alkaline phosphatase activities in regulation to crop species and fungal treatment. Landbauforsch Völkenrode 2004, 54, 1-5.

29. Kosteckas, R.; Marcinkevičienè, A. The integrated evaluation of the influence of catch crops and manure on spring barley agrocenosis in organic farming. Agron. Res. 2009, 7, 355-362.

30. Hendrikson, A.; Selmer-Olsen, A.R. Automatic Methods for Determination of Nitrate and Nitrite in Water and Soil Extracts. Analyst 1970, 95, 514-518. [CrossRef]

31. Nelson, D.; Sommers, L. Chemical Methods Soil Science Society of America Book Series; Soil Science Society of America: Madison, WI, USA, 1996; pp. 961-1010.

32. Nelson, D.W. Total Carbon, Organic Carbon, and Organic Matter. In Methods of Soil Analysis; Soil Science Society of America: Madison, WI, USA, 1996.

33. Murphy, J.; Riley, J.P. A modified single solution method for the determination of phosphate in natural waters. Anal. Chim. Acta 1962, 27, 31-36. [CrossRef]

34. Sparks, D.L.; Page, A.L.; Helmke, P.A.; Loeppert, R.H.; Zelazny, L.W.; He, L.; Vanwormhoudt, A. Charge Analysis of Soils and Anion Exchange; Chapter 41; Soil Science Society of America: Madison, WI, USA, 1996; pp. 1231-1253.

35. Aleixo, G.T.; Afonso, C.R.M.; Coelho, A.A.; Caram, R. Effects of omega phase on elastic modulus of Ti-Nb alloys as a function of composition and cooling rate. Solid State Phenom. 2008, 138, 393-398. [CrossRef]

36. Soon, Y.K.; Kalra, Y.P. A comparison of plant tissue digestion methods for nitrogen and phosphorus analyses. Can. J. Soil Sci. 1995, 75, 243-245. [CrossRef]

37. Walker, J.M.; Barber, S.A. Absorption of potassium and rubidium from the soil by corn roots. Plant Soil 1962, 17, 243-259. [CrossRef]

38. Saiya-Cork, K.R.; Sinsabaugh, R.L.; Zak, D.R. The effects of long term nitrogen deposition on extracellular enzyme activity in an Acer saccharum forest soil. Soil Biol. Biochem. 2002, 34, 1309-1315. [CrossRef]

39. Deforest, J.L. Soil Biology \& Biochemistry The influence of time, storage temperature, and substrate age on potential soil enzyme activity in acidic forest soils using MUB-linked substrates and L -DOPA. Soil Biol. Biochem. 2009, 41, 1180-1186.

40. Anugroho, F.; Kitou, M.; Nagumo, F.; Kinjo, K.; Jayasinghe, G.Y. Potential growth of hairy vetch as a winter legume cover crops in subtropical soil conditions. Soil Sci. Plant Nutr. 2010, 56, 254-262. [CrossRef]

41. Silvertown, J. Plant competition. Nature 1989, 337, 122-123. [CrossRef]

42. Lynch, J.P. Turner review no. 14. Roots of the second green revolution. Aust. J. Bot. 2007, 55, 493-512. [CrossRef]

43. Hammond, J.P.; Broadley, M.R.; White, P.J.; King, G.J.; Bowen, H.C.; Hayden, R.; Meacham, M.C.; Mead, A.; Overs, T.; Spracklen, W.P.; et al. Shoot yield drives phosphorus use efficiency in Brassica oleracea and correlates with root architecture traits. J. Exp. Bot. 2009, 60, 1953-1968. [CrossRef]

44. Hammond, J.P.; White, P.J. Sucrose transport in the phloem: Integrating root responses to phosphorus starvation. J. Exp. Bot. 2008, 59, 93-109. [CrossRef] [PubMed]

45. Schilling, G.; Gransee, A.; Deuhel, A.; Ležoviž, G.; Ruppel, S. Phosphorus availability, root exudates, and microbial activity in the rhizosphere. Z. Für Pflanz. Und Bodenkd 1998, 161, 465-478. [CrossRef]

46. Sujatha, D.V.; Kavitha, P.; Naidu, M.V.S. Influence of Green Manure and Potassium Nutrition on Soil Potassium Fractions and Yield of Rice Crop. Int. J. Curr. Microbiol. Appl. Sci. 2017, 6, 13-23. [CrossRef]

47. Amin, M.; Jamshid, H.R.; Khan, E.A.; Ramzan, M. Comparative response of diverse rice varieties to green manuring (Sesbania aculeata). J. Res. Sci. 2005, 16, 39-43.

48. Elfstrand, S.; Hedlund, K.; Mårtensson, A. Soil enzyme activities, microbial community composition and function after 47 years of continuous green manuring. Appl. Soil Ecol. 2007, 35, 610-621. [CrossRef]

49. Maltais-Landry, G.; Frossard, E. Similar phosphorus transfer from cover crop residues and water-soluble mineral fertilizer to soils and a subsequent crop. Plant Soil 2015, 393, 193-205. [CrossRef]

50. Alori, E.T.; Glick, B.R.; Babalola, O.O. Microbial phosphorus solubilization and its potential for use in sustainable agriculture. Front Microbiol. 2017, 8, 1-8. [CrossRef] 
51. Gahoonia, T.S.; Nielsen, N.E. Phosphorus (P) uptake and growth of a root hairless barley mutant (bald root barley, brb) and wild type in low- and high-P soils. Plant cell Env. 2003, 26, 1759-1766. [CrossRef]

52. Shane, M.W.; Cramer, M.D.; Funayama-Noguchi, S.; Cawthray, G.R.; Millar, A.H.; Day, D.A.; Lambers, H. Developmental physiology of cluster-root carboxylate synthesis and exudation in harsh hakea. Expression of phosphoenolpyruvate carboxylase and the alternative oxidase. Plant Physiol. 2004, 135, 549-560. [CrossRef]

53. Kai, M.; Takazumi, K.; Adachi, H.; Wasaki, J.; Shinano, T.; Osaki, M. Cloning and characterization of four phosphate transporter cDNAs in tobacco. Plant Sci. 2002, 163, 837-846. [CrossRef]

54. Mukumbareza, C.; Muchaonyerwa, P.; Chiduza, C. Effects of oats and grazing vetch cover crops and fertilisation on microbial biomass and activity after five years of rotation with maize. South Afr. J. Plant Soil. 2015, 32, 189-197. [CrossRef]

55. Piotrowska-Długosz, A.; Wilczewski, E. Changes in enzyme activities as affected by green-manure catch crops and mineral nitrogen fertilization. Zemdirbyste 2014, 101, 139-146. [CrossRef]

56. Thorup-Kristensen, K.; Magid, J.; Jensen, L.S. Catch crops and green manures as biological tools in nitrogen management in temperate zones. Adv. Agron. 2003, 79, 227-302.

57. Dinesh, R.; Suryanarayana, M.A.; Ghoshal Chaudhuri, S.; Sheeja, T.E. Long-term influence of leguminous cover crops on the biochemical properties of a sandy clay loam Fluventic Sulfaquent in a humid tropical region of India. Soil Tillage Res. 2004, 77, 69-77. [CrossRef]

58. Tejada, M.; García-Martínez, A.M.; Parrado, J. Effects of a vermicompost composted with beet vinasse on soil properties, soil losses and soil restoration. Catena 2009, 77, 238-247. [CrossRef]

59. Roldán, A.; Caravaca, F.; Hernández, M.T.; García, C.; Sánchez-Brito, C.; Velásquez, M.; Tiscareño, M. No-tillage, crop residue additions, and legume cover cropping effects on soil quality characteristics under maize in Patzcuaro watershed (Mexico). Soil Tillage Res. 2003, 72, 65-73. [CrossRef]

60. Yang, K.; Zhu, J.; Yan, Q.; Zhang, J. Soil enzyme activities as potential indicators of soluble organic nitrogen pools in forest ecosystems of Northeast China. Ann. Sci. 2012, 69, 795-803. [CrossRef]

61. Xu, Z.; Yu, G.; Zhang, X.; Ge, J.; He, N.; Wang, Q.; Wang, D. The variations in soil microbial communities, enzyme activities and their relationships with soil organic matter decomposition along the northern slope of Changbai Mountain. Appl. Soil Ecol. 2014, 86, 19-29. [CrossRef]

62. Shen, Q.; Wen, Z.; Dong, Y.; Li, H.; Miao, Y.; Shen, J. The responses of root morphology and phosphorus-mobilizing exudations in wheat to increasing shoot phosphorus concentration. J. Environ. Eva. Plant Biol. 2018, 10, 1-11. [CrossRef]

63. Margalef, O.; Sardans, J.; Fernández-Martínez, M.; Molowny-Horas, R.; Janssens, I.A.; Ciais, P.; Goll, D.; Richter, A.; Obersteiner, M.; Asensio, D.; et al. Global patterns of phosphatase activity in natural soils. Sci. Rep. 2017, 7, 1-13. [CrossRef]

64. Waldrop, M.P.; Harden, J.W.; Turetsky, M.R.; Petersen, D.G.; McGuire, A.D.; Briones, M.J.I.; Churchill, A.C.; Doctor, D.H.; Pruett, L.E. Bacterial and enchytraeid abundance accelerate soil carbon turnover along a lowland vegetation gradient in interior Alaska. Soil Biol. Biochem. 2012, 50, 188-198. [CrossRef]

65. Hossain, M. Correlations of available phosphorus and potassium with $\mathrm{pH}$ and organic matter content in the different forested soil and hill tracts banagadesh. Int. J. Soil Eros. 2014, 4, 7-10.

66. Penn, C.J.; Camberato, J.J. A Critical Review on Soil Chemical Processes that Control How Soil pH Affects Phosphorus Availability to Plants. Agriculture 2019, 9, 120. [CrossRef]

67. Khadka, D.; Lamichhane, S.; Thapa, B. Khadka, D.; Lamichhane, S.; Thapa, B. Assessment of relationship between soil pH and macronutrients, Western Nepal. J. Bio. Physi. Sci. 2016, 6, 303-311.

68. Marcin, K.; MICHA£, S.; ANWAR, H.J. Relationship between available and exchangeable K. Pol. J. Soil Sci. 2005, 2, 179-186.

69. Wallenius, K.; Rita, H.; Mikkonen, A.; Lappi, K.; Lindström, K.; Hartikainen, H.; Raateland, A.; Niemi, R.M. Effects of land use on the level, variation and spatial structure of soil enzyme activities and bacterial communities. Soil Biol. Biochem. 2011, 43, 1464-1473. [CrossRef]

70. Cenini, V.L.; Fornara, D.A.; McMullan, G.; Ternan, N.; Carolan, R.; Crawley, M.J.; Clément, J.C.; Lavorel, S. Linkages between extracellular enzyme activities and the carbon and nitrogen content of grassland soils. Soil Biol. Biochem. 2016, 96, 198-206. [CrossRef]

71. Xing, S.; Chen, C.; Zhou, B.; Zhang, H.; Nang, Z.; Xu, Z. Soil soluble organic nitrogen and active microbial characteristics under adjacent coniferous and broadleaf plantation forests. J. Soils Sediments 2010, 10, 748-757. [CrossRef] 
72. Hallama, M.; Pekrun, C.; Lambers, H.; Kandeler, E. Hidden miners - the roles of cover crops and soil microorganisms in phosphorus cycling through agroecosystems. Plant Soil. 2019, 434, 7-45. [CrossRef]

73. Olander, L.P.; Vitousek, P.M. Regulation of soil phosphatase and chitinase activity by N and P availability. Biogeochemistry 2000, 49, 175-190. [CrossRef]

74. Balota, E.L.; Chaves, J.C.D. Enzymatic activity and mineralization of carbon and nitrogen in soil cultivated with coffee and green manures. Rev. Bras. Ciência Do Solo 2010, 34, 1573-1583. [CrossRef] 